\title{
Study of Lowlands Drainage Problems, Case Study Kamal El-Den Hessen Reclaimed Area, North Sinai, Egypt
}

\author{
Mohamed Gabr \\ Civil Engineering Department, High Institute for Engineering and Technology, New Damietta, Egypt \\ Email: m_egabr@yahoo.com
}

How to cite this paper: Gabr, M. (2018) Study of Lowlands Drainage Problems, Case Study Kamal El-Den Hessen Reclaimed Area, North Sinai, Egypt. Journal of Water Resource and Protection, 10, 857-869. https://doi.org/10.4236/jwarp.2018.109049

Received: July 19, 2018

Accepted: September 8, 2018

Published: September 11, 2018

Copyright $\odot 2018$ by author and Scientific Research Publishing Inc. This work is licensed under the Creative Commons Attribution International License (CC BY 4.0).

http://creativecommons.org/licenses/by/4.0/

\section{(c) (i) Open Access}

\begin{abstract}
This paper deals mainly to study and solve field drainage problems in Kamal El-Den Hessen new reclaimed area (1650 hectares), North Sinai Egypt, where many farmers complain about the formation of water ponds in their lands, bad soil drainage, soil salinity, and low yields rate. Intensive field investigations were carried out regarding, topographic survey, digging 22 boreholes, instilling observation wells, measuring groundwater salinity and assessing the existing drainage network. The results showed that ground surface levels were ranging from $1.5 \mathrm{~m}$ to $4.28 \mathrm{~m}$ above mean sea level, predominated soil was sandy with a permeability coefficient ranged from 0.82 to $2.68 \mathrm{~m} /$ day, an impervious clay layer lies at 6.0 to $7.0 \mathrm{~m}$ below ground surface, and the groundwater salinity ranges from 4 to $12 \mathrm{dS} / \mathrm{m}$ high salinity for water ponds were observed at the observation wells that lay in the lift side of Kamal El-Den Hessen Canal. Lands surrounding Kamal El-Den Hessen Canal have high levels. The measured groundwater depths of the western observation wells were $0.50 \mathrm{~m}$ below ground surface and in the eastern wells ranging from 1.0 to 1.50 $\mathrm{m}$. The analysis of results showed that field drainage problems that increased groundwater levels were: 1) infiltration water coming from the high-cultivated areas at the lift bank of Kamal El-Den Hessen Canal, 2) the impervious clay layers increasing the horizontal infiltration towards low lands and increase ponds areas. 3) Main Gelbana Drain cross-section needs dredging. It is recommended to dredge the Main Gelbana Drain and modified its cross-section to collect water from water ponds, filling the lowland areas utilizing sandy soil in the high lands, adopting types of crops grown to match with crop salt tolerant levels and soil and water salinity levels and constructing subsurface drainage network to decrease groundwater levels.
\end{abstract}

\section{Keywords}

Drainage Problems, Groundwater Levels, Soil Salinity, Soil Permeability 


\section{Introduction}

The shortage of water resources forces many countries like Egypt to reuse agriculture drainage water of good quality in irrigation or to mix it with Nile fresh water to improve its quality to utilize in the cultivation of newly reclaimed areas [1]. In the long run, the low-quality irrigation water causes the rising of drainage problems and soil salinity [2] [3]. New land reclamation projects that lie in arid and semi-arid regions, usually the groundwater level is deep and the drainage network did not impalement coincidence with irrigation network to compact the project cost. After the operation of the project, the drainage problems such as increasing soil salinity, waterlogging, and rising groundwater table to the effective root zone was raised. Therefore, drainage should be practiced in parallel with irrigation to make sure maximum yields and for environmental safety in all irrigation projects [4] [5] [6]. Drainage problems dealt with impermeable soils, the high water table in depression areas, and side hill seepage [7]. To discuss drainage, separation has to be made between drainage of groundwater and drainage of surface water. Groundwater drainage helps to control soil salinity for irrigated lands [8]. The surface drainage may also be required to remove excess rainfall or increase irrigation water, especially for soil with low leakage rates [9] [10] [11]. Surface drainage is also needed if rice is grown. Shallow surface drains can also be used to filter salts. For example, with ditches, only $0.4 \mathrm{~m}$ deep, farmers in Egypt have managed to tame their new saline land. If rice is grown, alternately with dry foot crops, such as the old lands of the River Nile Delta, such as subsurface drainage required to control the groundwater of non-rice crops and to mitigate the risk of extreme percolation losses in periods that rice is grown [10] [12]. The solution worked out in Egypt is to grow rice in drainage units by backing up a device close to the drainage outlet for the water table control. The drainage of groundwater through horizontal water drainage can be adopted by pumping vertical wells in case of a permeable aquifer. The groundwater is often saline in arid lowlands, and often the salinity is increased with depth. Deep vertical drainage wells will produce highly saline water weak for re-use and difficult to dispose of [13] [14]. Impermeable soils, silty/clayey soil texture with flat topography and poor infiltration are classified as rates impermeable soils [15]. Depression areas can be defined as low wet areas where a significant amount of water ponds after rainfalls, there is no deep percolation obtainable for the surplus water. If the water ponds greater than $3 \mathrm{~m}$ in diameter or greater than $10 \mathrm{~cm}$ deep, then the problem should be treated as a depression area [16], installation of boreholes and observation wells are essentially for analyzing the soils and studying the water table depths over time. Side bank seepage can arise where a relatively permeable soil (sandy) overlies a relatively impermeable soil (silt/clay) on a slope. Excess water percolates into the sandy soil at high elevations. In clay soil, it cannot stay downwards and it is forced to move horizontally and to seep out where the sand layer ends. Sidehill seepage can also occur where clay soils have been reworked into banks or hills by machinery [17] [18] [19]. There will be large voids left in the disturbed clay since it is essentially impossible to re-compact it to its original state. 
These large voids ratio will permit the water to move freely into the disturbed profile. This type of drainage problem can produce enough water to preserve a wide flat fairway, neighboring to the slope, very wet. This research deals mainly to identify and investigate the field drainage problems of Kamal El-Den Hessen Canal new reclaimed area (1650 hectares) at the North of Sinai, Egypt, where many farmers complain about the formation of water ponds in their lands, bad soil drainage, and low yields rate. As well as recommend the appropriate solutions.

\section{Materials and Methods}

\subsection{Materials}

Kamal El-Den Hessen Canal region, North Sinai Egypt was selected to be a study area. It lies in the North Sinai Peninsula, where the North Sinai Development project (NSDP) to reclaim and cultivate 168 thousand hectares (Figure 1). El-Sheikh Gaber Canal is the main feeder for the NSDP, the annual water resources for the project are 4.5 Millard $\mathrm{m}^{3}$. The water resources in the study area are Nile freshwater mixed with agriculture drainage wastewater in a ratio 1:1 with salinity up to 1000 ppm [20]. Kamal El-Den Hessen Canal area served is 1650 hectares and it takes its water from the South East El-Qantara Canal (Figure 2). The Water Resources, Irrigation, and Infrastructures Sector, North Sinai, Ministry of Water Resources and Irrigation Egypt has operated the canal since 2000 . The canal was lined with plain concrete since 2000 to prevent seepage losses where it is passed through sandy soil, the canal length is $10.500 \mathrm{~km}$, water depth $1.5 \mathrm{~m}$, bed width $1.5 \mathrm{~m}$ water slope $15 \mathrm{~cm} / \mathrm{km}$, and inside slopes 2:1. Surface drainage network consists of Main Gelbana Drain and Tall Elhair Drain

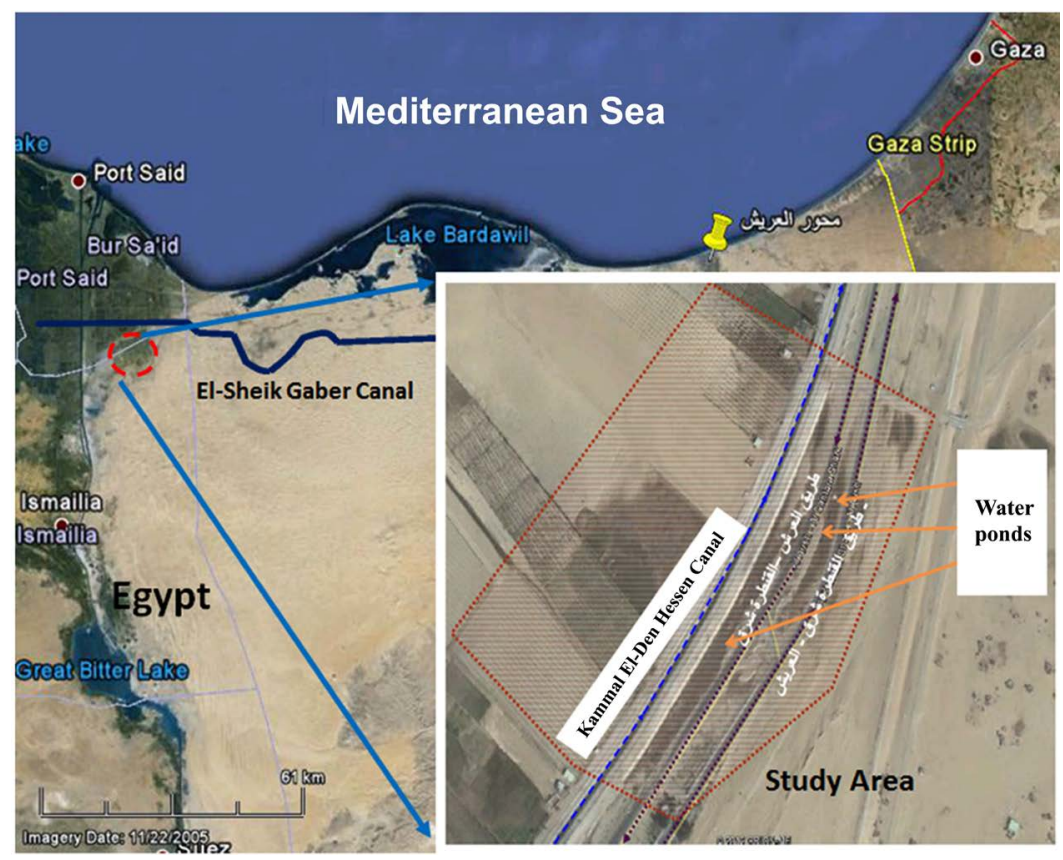

Figure 1. Location of study area. 


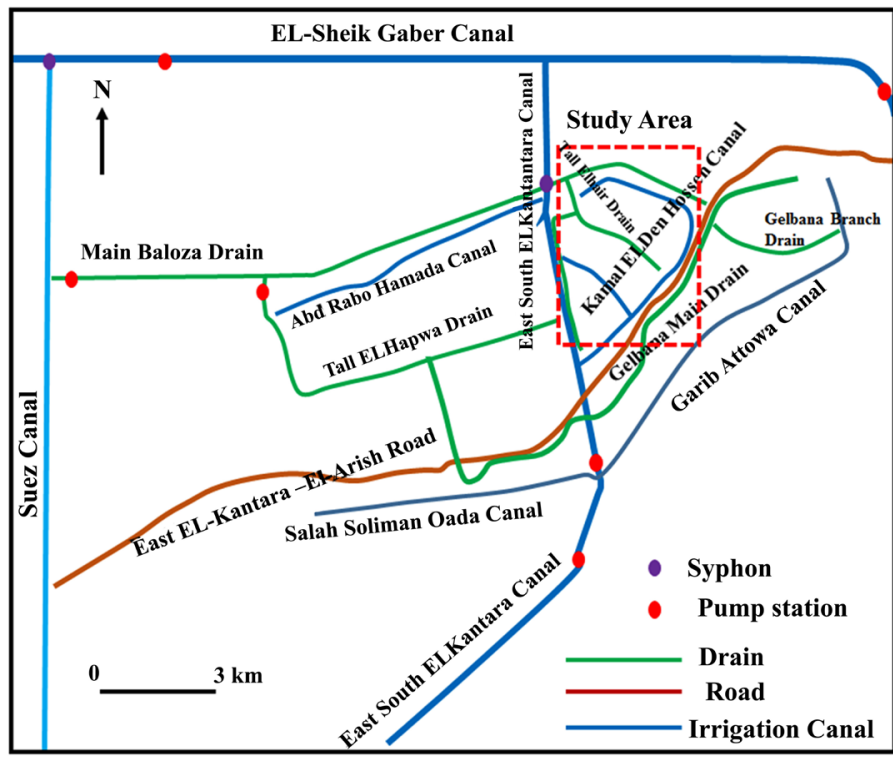

Figure 2. Irrigation and drainage canal networks in the study area.

(Figure 2). Many farmers complain about the formation of water ponds in their lands, bad soil drainage, and low yields rate. The studied area experiences a semi-arid climate type. The topography is sand terrain with large differences in elevations and steep slopes. The applied irrigation systems are sprinkler irrigation and drip irrigation. The surface drainage network was implemented together with irrigation facilities. Subsurface drainage networks did not implement till now. Wheat, sugar beet and corn are the major crops grown in the study area, besides vegetables, and fruits.

\subsection{Methods}

Eight infiltration paths were selected based on land topography, existing water ponds and irrigation canal (Kamal El-Den Hessen Canal). Twenty-two boreholes were carried out to describe land topography, soil permeability, groundwater levels and directions. Figure 3 shows the suggested infiltration paths, location of boreholes and the ground water observation wells distribution. Coordinates of the selected boreholes and groundwater observation wells for the infiltration paths coordinates were shown in Table 1. Topographic survey for the study area was carried out using double difference GPS Device by the Drainage Research Institute (DRI) team, National Water Research Center (NRC), Ministry of Water Resources and Irrigation (MWRI), Egypt. The existing drainage system was investigated where a group of 11 cross-section along the Main Gelbana Drain were measured at distances $0.00 \mathrm{~km}, 1.00 \mathrm{~km}, 1.300 \mathrm{~km}, 2.500 \mathrm{~km}, 4.200 \mathrm{~km}, 8.00 \mathrm{~km}$, $9.00 \mathrm{~km}, 10.50 \mathrm{~km}, 13.00 \mathrm{~km}, 15.00 \mathrm{~km}$, and $16.00 \mathrm{~km}$ from its outlet using total station survey instrument. The measured cross-sections were compared with designed cross-sections. The results showed that the main Gelbana Drain cross-section is suffering from deposition and needs dredging. Figure 4 shows the contour map, the ground surface levels were ranging from $1.5 \mathrm{~m}$ to $4.28 \mathrm{~m}$ 
Table 1. Coordinates of the selected boreholes and groundwater observation wells for the infiltration paths coordinates.

\begin{tabular}{|c|c|c|c|c|}
\hline $\begin{array}{l}\text { Symbols of boreholes } \\
\text { and groundwater } \\
\text { observation wells }\end{array}$ & $\begin{array}{c}\text { Infiltration Path } \\
\text { Number }\end{array}$ & $\begin{array}{c}\text { Vertical } \\
\text { coordinate }\end{array}$ & $\begin{array}{l}\text { Horizontal } \\
\text { coordinate }\end{array}$ & $\begin{array}{c}\text { Ground level } \\
\text { (m) }\end{array}$ \\
\hline A1 & \multirow{3}{*}{ Path No. 1} & 453548.2 & 3426591 & 2.55 \\
\hline A2 & & 453609.1 & 3426543 & 2.68 \\
\hline A3 & & 453665.4 & 3426498 & 2.81 \\
\hline A 4 & \multirow{3}{*}{ Path No. 2} & 453761.2 & 3426462 & 2.17 \\
\hline A5 & & 453796.4 & 3426438 & 2.08 \\
\hline A6 & & 453838.3 & 3426418 & 3.11 \\
\hline B7 & \multirow{3}{*}{ Path No. 3} & 453553.2 & 3426483 & 2.38 \\
\hline B8 & & 453534.7 & 3426397 & 2.17 \\
\hline B9 & & 453585.2 & 3426361 & 2.30 \\
\hline B11 & \multirow{2}{*}{ Path No. 4} & 453743.2 & 3426234 & 2.29 \\
\hline B12 & & 453767.1 & 3426212 & 2.3 \\
\hline $\mathrm{C} 13$ & \multirow{3}{*}{ Path No. 5} & 453386.5 & 3426400 & 2.79 \\
\hline $\mathrm{C} 14$ & & 453448.8 & 3426325 & 1.50 \\
\hline $\mathrm{C} 15$ & & 453510.4 & 3426243 & 1.74 \\
\hline $\mathrm{C} 16$ & \multirow{3}{*}{ Path No. 6} & 453629.4 & 3426160 & 2.05 \\
\hline $\mathrm{C} 17$ & & 453649.7 & 3426131 & 1.98 \\
\hline $\mathrm{C} 18$ & & 453689.8 & 3426097 & 3.43 \\
\hline D19 & \multirow{3}{*}{ Path No. 7} & 453838.3 & 3426168 & 1.77 \\
\hline D20 & & 453548.2 & 3426238 & 1.53 \\
\hline $\mathrm{D} 21$ & & 453609.1 & 3426153 & 2.01 \\
\hline D23 & \multirow{2}{*}{ Path No. 8} & 453575.4 & 3426035 & 2.11 \\
\hline D24 & & 453601.7 & 3425969 & 4.28 \\
\hline
\end{tabular}

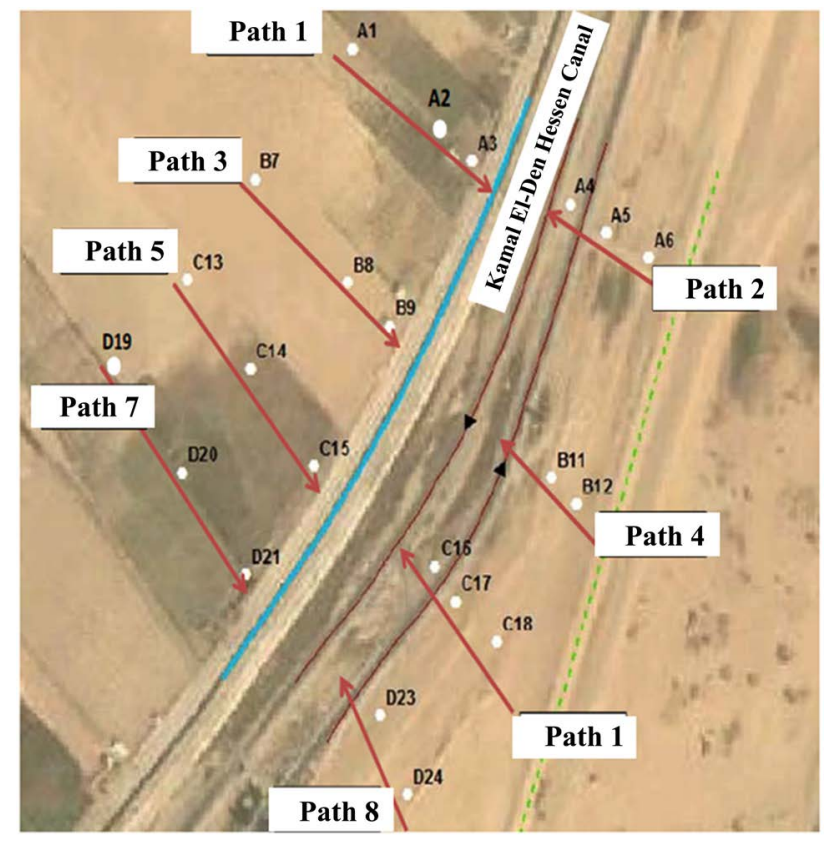

Figure 3. Suggested infiltration paths, 22 boreholes and observation wells distributions. 


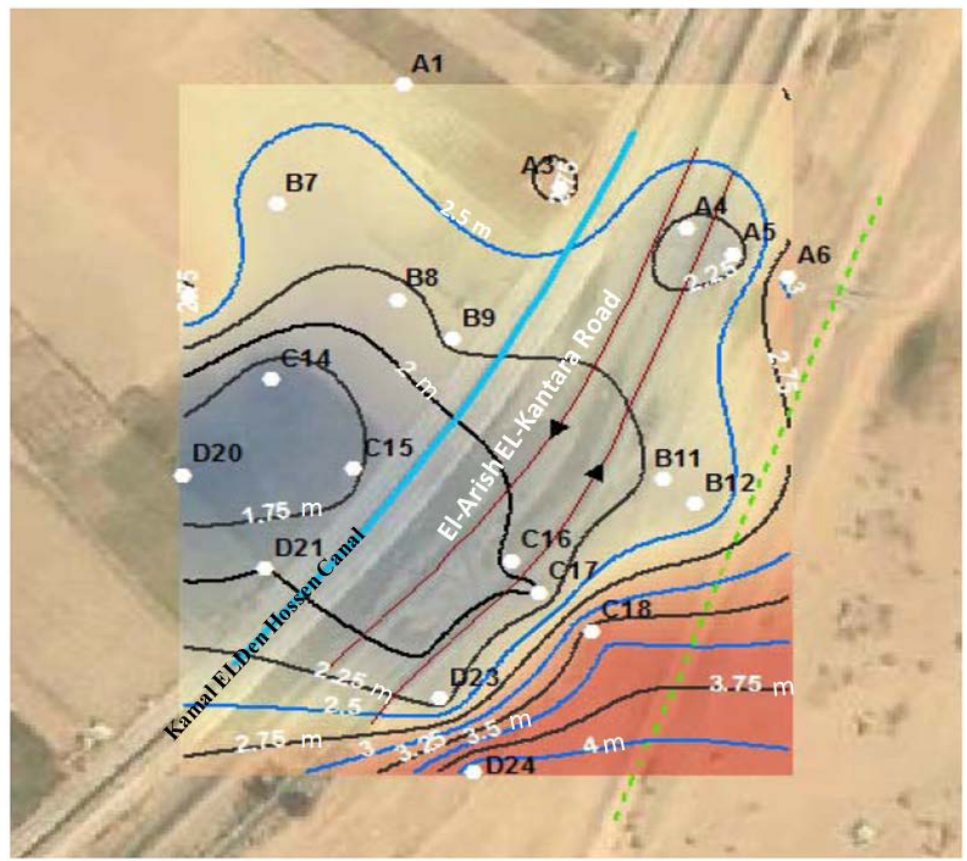

Figure 4. Contour map for the study area.

above mean sea level. A 22 soil classification and permeability tests were carried out [21], the results showed that, the predominate soil is sand (Table 2), measured coefficients of permeability was ranging from $0.82 \mathrm{~m} /$ day to $2.68 \mathrm{~m} /$ day as shown in Table 3. Average surface groundwater levels during the period from May 2013 to December 2013 were presented in Table 4, the groundwater depth was ranging from $0.1 \mathrm{~m}$ to $2.42 \mathrm{~m}$, and Figure 5 shows the average groundwater levels. A four deep groundwater monitoring wells (D1, D2, D3, and D4) of a depth of 9.0 $\mathrm{m}$ were implemented to monitor the depth and direction of the deep groundwater, the location of wells were selected near the surface groundwater well numbers A1, B9, C16, and D23, respectively, Table 5 shows deep and surface groundwater levels during the period (October 2013 to December 2013). The water quality of the infiltration water in terms of salinity was measured based on [22]; Table 6 shows measured average groundwater electric conductivity (EC) in $\mathrm{dS} / \mathrm{m}$ for the observation wells during the period from March 2013 to January 2014).

\section{Results and Discussion}

The results obtained from 22 boreholes soil samples (Table 1) showed that the soil surface layer was sandy soil with thin salt crest and changing to silt soil, the groundwater table was observed at $0.15 \mathrm{~m}$ above the ground surface to $1.25 \mathrm{~m}$ below ground surface (Table 2). An impervious clay layer lies at 6.0 to $7.0 \mathrm{~m}$ below ground surface, this layer increases horizontal percolation towards low-level lands. The results of soil permeability for the 22 location distributed in the study area showed the coefficient of permeability ranging from 0.82 to $2.68 \mathrm{~m} /$ day (Table 3). The depths of groundwater in the western observation wells were 0.50 $\mathrm{m}$ below ground surface and in the eastern wells, ranging from 1.0 to $1.50 \mathrm{~m}$, at 
Table 2. Soil Description and groundwater levels.

\begin{tabular}{ccccc}
\hline Symbol & Depth $(\mathrm{m})$ & Soil description & $\begin{array}{c}\text { Groundwater depth } \\
(\mathrm{m})\end{array}$ & $\begin{array}{c}\text { Ground level } \\
(\mathrm{m})\end{array}$ \\
\hline A1 & $0.00-2.00$ & sand & 1.19 & 2.55 \\
A2 & $0.00-1.60$ & sand & 1.85 & 2.68 \\
A3 & $0.00-2.00$ & sand & 1.73 & 2.81 \\
A4 & $0.00-1.50$ & sand & 1.82 & 2.17 \\
A5 & $0.00-1.60$ & sand & 1.92 & 2.08 \\
A6 & $0.00-2.00$ & sand & 1.80 & 3.11 \\
B7 & $0.00-2.00$ & sand & 1.51 & 2.38 \\
B8 & $0.00-2.00$ & sand & 1.64 & 2.17 \\
B9 & $0.00-2.00$ & sand & 1.70 & 2.30 \\
B11 & $0.00-1.40$ & sand & 2.18 & 2.29 \\
B12 & $0.00-1.10$ & sand & 1.89 & 2.30 \\
C13 & $0.00-2.00$ & sand & 1.23 & 2.79 \\
C14 & $0.00-2.00$ & sand & 1.33 & 1.50 \\
C15 & $0.00-2.00$ & sand & 1.37 & 1.74 \\
C16 & $0.00-2.00$ & sand & 1.98 & 2.05 \\
C17 & $0.00-1.40$ & sand & 1.86 & 1.98 \\
C18 & $0.00-1.10$ & sand & 2.42 & 3.43 \\
D19 & $0.00-0.80$ & sand & Dry & 1.77 \\
D20 & $0.80-2.00$ & Sandy clay & 0.1 & 1.53 \\
D21 & $0.00-2.00$ & sand & 1.64 & 2.01 \\
D23 & $0.00-2.00$ & sand & 1.77 & 2.11 \\
D24 & $0.00-2.00$ & sand & Dry & 4.27 \\
\hline & & & & \\
\hline
\end{tabular}

Table 3. Measured coefficient of permeability.

\begin{tabular}{cccc}
\hline Well Number & Vertical coordinate & Horizontal coordinate & $\begin{array}{c}\text { Hydraulic conductivity } \\
(\mathrm{m} / \text { day })\end{array}$ \\
\hline A1 & 453548.2 & 3426591 & 1.89 \\
A2 & 453609.1 & 3426543 & 2.68 \\
A3 & 453665.4 & 3426498 & 1.93 \\
A4 & 453761.2 & 3426462 & 0.93 \\
A6 & 453838.3 & 3426418 & 2.08 \\
B7 & 453553.2 & 3426483 & 1.19 \\
B8 & 453534.7 & 3426397 & 2.10 \\
B9 & 453585.2 & 3426361 & 0.89 \\
B11 & 453743.2 & 3426234 & 0.82 \\
B12 & 453767.1 & 3426212 & 2.10 \\
C14 & 453448.8 & 3426325 & 1.26 \\
C15 & 453510.4 & 3426243 & 1.36 \\
C16 & 453629.4 & 3426160 & 1.12 \\
\hline & & & \\
\hline
\end{tabular}




\section{Continued}

\begin{tabular}{llll}
\hline C18 & 453689.8 & 3426097 & 0.68 \\
D 19 & 453535.7 & 3426316 & 0.66 \\
D 20 & 453381.6 & 3426238 & 1.19 \\
D 21 & 453443.6 & 3426153 & 2.10 \\
D23 & 453575.4 & 3426035 & 0.89 \\
D24 & 453601.7 & 3425969 & 0.82 \\
\hline
\end{tabular}

Table 4. Average surface groundwater levels during the period (May 2013 to December 2013).

\begin{tabular}{ccccc}
\hline Symbol & Depth (m) & $\begin{array}{c}\text { Average } \\
\text { groundwater depth (m) }\end{array}$ & $\begin{array}{c}\text { Average ground } \\
\text { water levels }(\mathrm{m})\end{array}$ & $\begin{array}{c}\text { Ground level } \\
(\mathrm{m})\end{array}$ \\
\hline A1 & & 1.309 & 1.19 & 2.55 \\
A2 & Path No. 1 & 0.888 & 1.85 & 2.68 \\
A3 & & 1.08 & 1.73 & 2.81 \\
A4 & & 0.353 & 1.82 & 2.17 \\
A5 & Path No. 2 & 0.169 & 1.92 & 2.08 \\
A6 & & 1.32 & 1.80 & 3.11 \\
B7 & & 0.809 & 1.51 & 2.38 \\
B8 & Path No. 3 & 0.52 & 1.64 & 2.17 \\
B9 & & 0.591 & 1.70 & 2.30 \\
B11 & & 0.11 & 2.18 & 2.29 \\
B12 & Path No. 4 & 0.464 & 1.89 & 2.30 \\
C13 & & 1.60 & 1.23 & 2.79 \\
C14 & Path No. 5 & 0.152 & 1.33 & 1.50 \\
C15 & & 0.399 & 1.37 & 1.74 \\
C16 & & 0.086 & 1.98 & 2.05 \\
C17 & Path No. 6 & 0.133 & 1.86 & 1.98 \\
C18 & & 1.144 & 2.42 & 3.43 \\
D 19 & & Dry & Dry & 1.53 \\
D 20 & Path No. 7 & 0.1 & 1.43 & 1.53 \\
D 21 & & 0.432 & 1.64 & 2.01 \\
D23 & & 0.332 & Dry & 2.11 \\
D24 & & & & 4.27 \\
\hline
\end{tabular}

Table 5. Deep and surface groundwater levels during the period (October 2013 to December 2013).

\begin{tabular}{cccccccc}
\hline \multirow{2}{*}{$\begin{array}{c}\text { Deep Well } \\
\text { Number }\end{array}$} & $\begin{array}{c}\text { Surface } \\
\text { Well } \\
\text { Number }\end{array}$ & \multicolumn{5}{c}{ October } & \multicolumn{4}{c}{ Deep groundwater depth (cm) } \\
\cline { 3 - 7 } & & Deep Well & Surface Well & Deep Well & Surface Well & Deep Well & Surface Well \\
\hline D1 & A1 & 145 & 115 & 148 & 123 & 150 & 125 \\
D2 & B9 & 60 & 58 & 62 & 62 & 65 & 62 \\
D3 & C16 & 70 & 10 & 72 & 14 & 73 & 13 \\
D4 & D23 & 30 & 29 & 45 & 31 & 48 & 30 \\
\hline
\end{tabular}


Table 6. Measured average groundwater electric conductivity (EC) in $\mathrm{dS} / \mathrm{m}$ for the observation wells during the period from March 2013 to January 2014).

\begin{tabular}{|c|c|c|c|c|c|c|c|c|}
\hline $\begin{array}{c}\text { Well } \\
\text { Number }\end{array}$ & March & July & August & September & October & November & December & January \\
\hline $\mathrm{A} 1$ & 2.45 & $\mathrm{ND}^{1}$ & ND & 4.5 & 2.25 & 2.5 & 2.25 & 2.65 \\
\hline $\mathrm{A} 2$ & & 2.55 & 2.77 & 9.28 & 3.1 & 9.50 & 2.80 & 2.85 \\
\hline $\mathrm{A} 3$ & 3.69 & 2.40 & 2.56 & 3.16 & 7.45 & 8.20 & 9.1 & 8.31 \\
\hline A4 & 7.2 & 1.53 & 1.55 & 1.05 & 1.76 & 1.97 & 9.15 & 8.27 \\
\hline A5 & 7.2 & 0.96 & 0.96 & 2.18 & 0.50 & 0.45 & 0.54 & 0.76 \\
\hline A6 & ND & 1.51 & 1.52 & 1.36 & 1.64 & 1.50 & 5.10 & 5.98 \\
\hline B7 & 5.08 & $\mathrm{ND}$ & ND & 7.1 & 5.4 & 6.00 & 6.02 & 6.52 \\
\hline B8 & 8.21 & 4.1 & 4.50 & 6.51 & 7.3 & 8.00 & 6.25 & 7.50 \\
\hline B9 & 21.1 & 3.11 & 3.51 & 13.50 & 8.20 & 15.20 & 15.10 & 15.30 \\
\hline B11 & 6.82 & 1.42 & 1.41 & 1.47 & 1.51 & 1.27 & 6.00 & 5.90 \\
\hline B12 & 5.2 & 1.06 & 1.06 & 1.76 & 1.54 & 1.52 & 6.50 & 6.39 \\
\hline $\mathrm{C} 13$ & 28.09 & 7.20 & ND & ND & ND & ND & 29.40 & 29.90 \\
\hline $\mathrm{C} 14$ & 18.50 & 12.0 & 12.45 & 55.8 & 57.5 & 55.00 & 52.1 & 52.4 \\
\hline $\mathrm{C} 15$ & 53.4 & 17 & 17.85 & 89.20 & 80.00 & 88.15 & 95.70 & 90.7 \\
\hline $\mathrm{C} 16$ & 21.8 & 3.50 & 2.51 & 2.47 & 2.45 & 2.15 & 8.25 & 7.67 \\
\hline $\mathrm{C} 17$ & 8.6 & 0.15 & 0.16 & 1.47 & 1.50 & 0.15 & 6.15 & 6.25 \\
\hline $\mathrm{C} 18$ & 9.2 & 0.36 & 0.36 & ND & ND & ND & ND & ND \\
\hline D 20 & 19.5 & 10.14 & 10.14 & ND & ND & ND & ND & ND \\
\hline D 21 & 19.5 & 3.50 & 3.20 & 15.32 & ND & ND & 19.7 & 20.70 \\
\hline D23 & ND & 3.10 & 2.64 & 1.85 & 60.00 & 16.17 & ND & ND \\
\hline $\mathrm{D} 24$ & 25.1 & $\mathrm{ND}$ & ND & ND & 30.00 & 0.15 & 16.50 & 15.72 \\
\hline
\end{tabular}

N.D. (not detected).

locations D20 and C16 water ponds have existed, (Table 4 and Figure 5) showed average surface groundwater levels. Studying of groundwater levels results of infiltration paths were shown in Figure 6 as following: 1) for infiltration path 1, at location A1 the mean groundwater depth was $1.36 \mathrm{~m}$, then decrease at A2 to $0.83 \mathrm{~m}$, then increased to $1.08 \mathrm{~m}$ at A3. 2) For infiltration path 2, at location A4 the mean groundwater depth was $0.35 \mathrm{~m}$, then decrease at $\mathrm{A} 5$ to $0.16 \mathrm{~m}$, and then increased to $1.31 \mathrm{~m}$ at A6. 3) For infiltration path 3, at location B7the mean groundwater depth was $0.8 \mathrm{~m}$, then decrease at $\mathrm{B} 8$ to $0.53 \mathrm{~m}$ and then increased to $0.6 \mathrm{~m}$ at B9. 4) For infiltration path 4 , at location B11 the mean groundwater depth was $0.11 \mathrm{~m}$, then decrease at B12 to $0.41 \mathrm{~m} .5$ ) for infiltration path 5, at location $\mathrm{C} 13$ the mean groundwater depth was $1.56 \mathrm{~m}$, then decrease at C14 to $0.17 \mathrm{~m}$, then increased to $0.4 \mathrm{~m}$ at $\mathrm{C} 15.6$ ) For infiltration path 6, at location $\mathrm{C} 16$ the mean groundwater depth was $0.07 \mathrm{~m}$, then increased at $\mathrm{C} 17$ to $0.12 \mathrm{~m}$, and then increased to $1.01 \mathrm{~m}$ at $\mathrm{C} 18.7$ ) For infiltration path 7, at location D19 no 


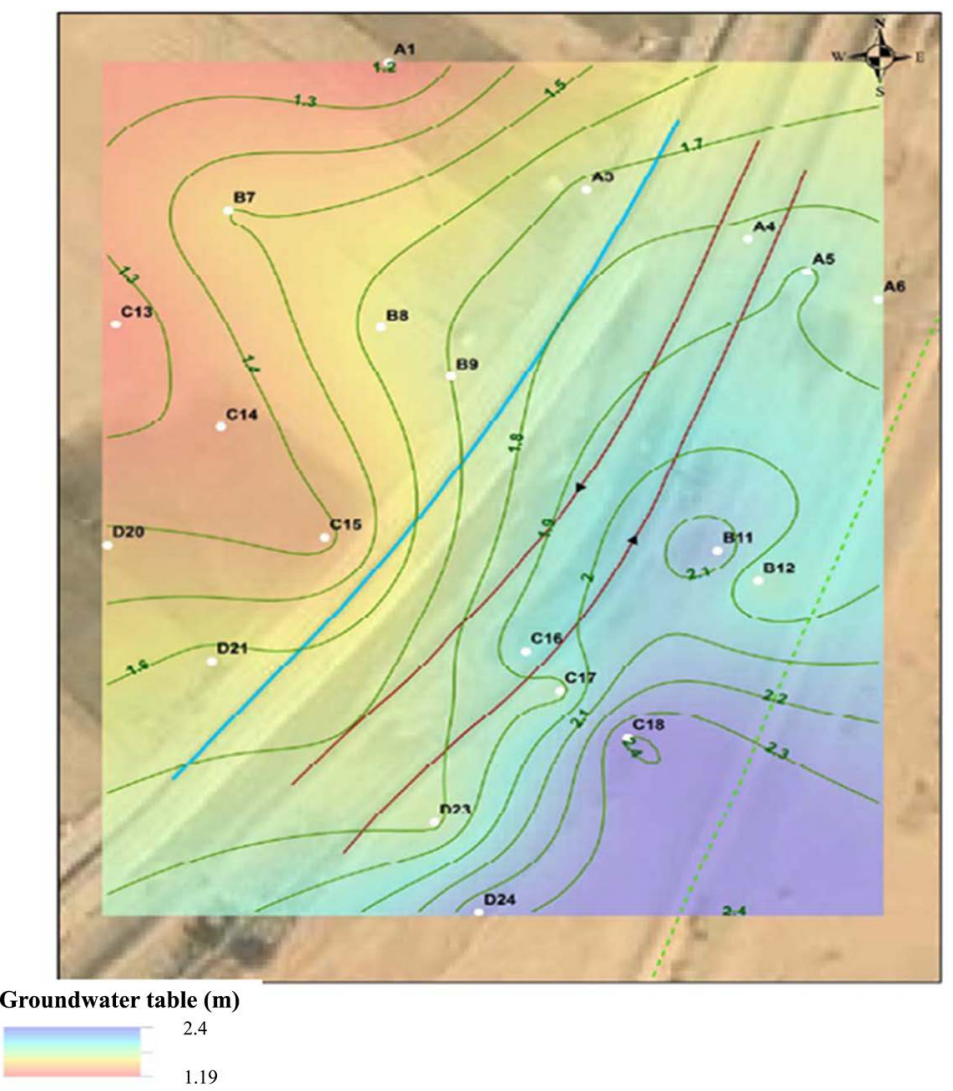

Figure 5. Average groundwater levels.

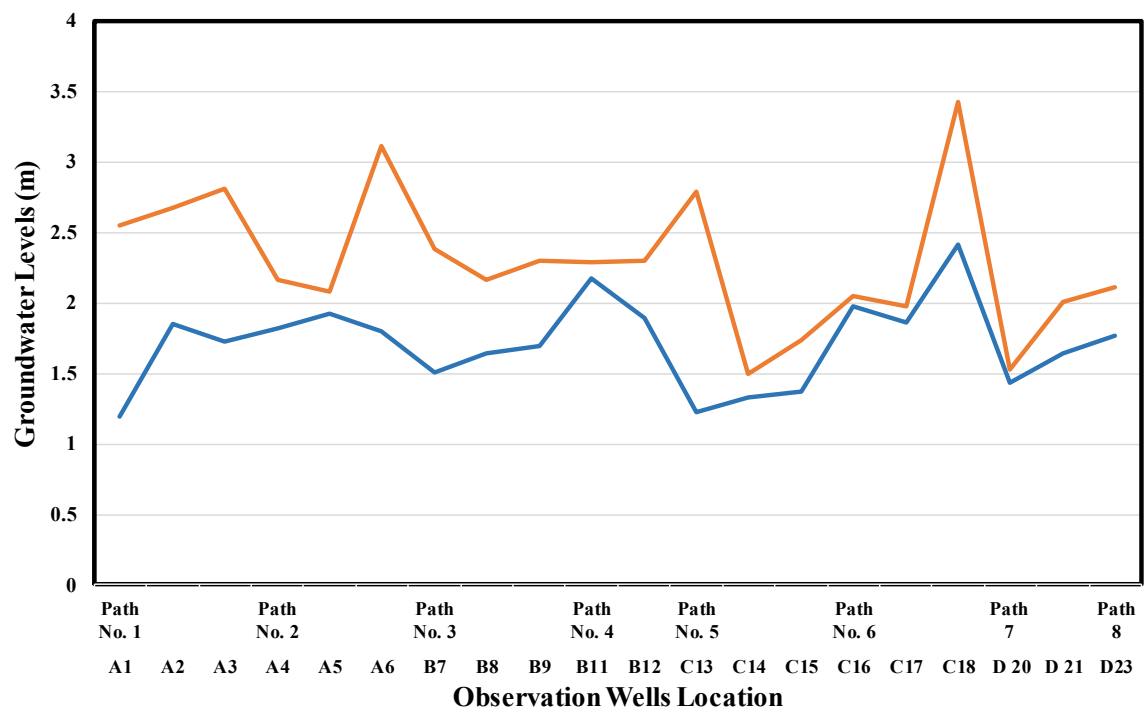

- Average ground water levels (m) Ground level (m)

Figure 6. Average groundwater levels through infiltration paths $1,2,3,4,5,6,7$, and 8 .

groundwater (dry well), at location D20 the mean groundwater depth was 1.43 $\mathrm{m}$, then decrease at D21 to $0.37 \mathrm{~m}$. 8) For infiltration path 8, at location D23 the mean groundwater depth was $0.34 \mathrm{~m}$, and at location D24 no groundwater (dry 
well). Table 5, shows the results for surface and deep groundwater levels measurements during the period (October 2013 to December 2013) that, maximum deep groundwater depth in well D1 was $150 \mathrm{~cm}$, minimum $145 \mathrm{~cm}$, and the average $147.67 \mathrm{~cm}$, compared to surface well A1 maximum surface groundwater depth was $125 \mathrm{~cm}$, and minimum $121 \mathrm{~cm}$ and the average value was $121 \mathrm{~cm}$, so there is no percolation from bottom to topsoil. Maximum deep groundwater depth in well D2 was $65 \mathrm{~cm}$ and the minimum $60 \mathrm{~cm}$ and the average $62.33 \mathrm{~cm}$ compared to surface well B9 maximum surface groundwater depth was $65 \mathrm{~cm}$, and the minimum $62 \mathrm{~cm}$ and the average value was $60.76 \mathrm{~cm}$. Maximum deep groundwater depth in well D3 was $73 \mathrm{~cm}$, the minimum $70 \mathrm{~cm}$, and the average $62.33 \mathrm{~cm}$ compared to surface well C16 maximum surface groundwater depth was $14 \mathrm{~cm}$, the minimum was $10 \mathrm{~cm}$ and the average value was $12.33 \mathrm{~cm}$. Maximum deep groundwater depth in well D4 was $48 \mathrm{~cm}$, the minimum was $30 \mathrm{~cm}$ and the average $41 \mathrm{~cm}$ compared to surface well D23 maximum surface groundwater depth was $31 \mathrm{~cm}$, the minimum was $29 \mathrm{~cm}$ and the average value was $30 \mathrm{~cm}$ so there is no percolation from bottom to topsoil. Table 6 , shows the measured average groundwater electric conductivity (EC) in $\mathrm{dS} / \mathrm{m}$ for the observation wells during the period from March 2013 to January 2014. The groundwater salinity range from 4 to $12 \mathrm{dS} / \mathrm{m}$, the groundwater quality is classified as medium saline water according to [23], high salinity for water ponds were observed at C13, C14, C15, D20, and D21 that lay in the lift side of Kamal El-Den Hessen Canal, where water percolation from high level cultivated areas towards low-level lands. Also the high evaporation rates lead to increase the salinity degree for the water ponds.

\section{Conclusion and Recommendations}

Many farmers complain about the formation of water ponds in their lands, bad soil drainage, and low yields rate in the Kamal El-Den Hessen new reclaimed area (1650 hectares) lies at the North Sinai Egypt. The study concluded that constant monitoring of soil permeability, salinity, irrigation water, groundwater levels, and groundwater salinity levels in the newly reclaimed lands is a good indicator to check irrigation drainage network efficiency, and changing types of crops grown to match with crop salt tolerant levels and soil and water salinity levels. Intensive field investigations were carried out during the period from March 2013 to January 2014 regarding, topographic survey using double difference GPS Device, assessing the existing drainage network, digging 22 boreholes to classify soils and testing soil permeability, instilling observation wells to monitor groundwater levels fluctuations, and measuring groundwater salinity. The analysis of results for field investigation of Kamal El-Den Hessen region showed that the ground surface levels were ranging from $1.5 \mathrm{~m}$ to $4.28 \mathrm{~m}$ above mean sea level, the soil classification analysis showed that the predominant soil is sandy soil, and the soil permeability was ranged from 0.82 to $2.68 \mathrm{~m} /$ day. The depths of groundwater in the western observation wells were $0.50 \mathrm{~m}$ below ground surface 
and in the eastern wells, ranging from 1.0 to $1.50 \mathrm{~m}$. The groundwater salinity ranges from 4 to $12 \mathrm{dS} / \mathrm{m}$, high salinity for water ponds were observed at the observation wells that lay in the lift side of Kamal El-Den Hessen Canal, where water percolation from high level cultivated areas towards low-level lands. Also the high evaporation rates lead to increase the salinity degree for the water ponds. Field drainage problems that increased groundwater levels are: An impervious clay layer lies at 6.0 to $7.0 \mathrm{~m}$ below ground surface increases the horizontal infiltration towards low lands and increase ponds areas. The lands surrounding Kamal El-Den Hessen Canal have a high level; the ground surface sloped from to Kamal El-Den Hessen Canal to Main Gelbana Drain. Main Gelbana Drain crosssection needs dredging. The Infiltration water comes from the high-cultivated areas at the lift bank of Kamal El-Den Hessen Canal. It is recommended to dredging Main Gelbana Drain and modified its cross-section to collect water from water ponds, filling the lowland areas utilizing sandy soil in the high lands, and constructing subsurface drainage network to decrease groundwater levels.

\section{Acknowledgements}

I am grateful for the outstanding logistical and technical support provided by the Water Resources, Irrigation and Infrastructures Sector, North Sinai, and the Drainage Research Institute (DRI), National Water Research Center (NRC), Ministry of Water Resources and Irrigation (MWRI), Egypt.

\section{Conflicts of Interest}

The author declares no conflicts of interest regarding the publication of this paper.

\section{References}

[1] Mohamed, G. and Medhat, E.L. (2018) Study of the Quality of Irrigation Water in South-East El-Kantara Canal, North Sinai, Egypt. IJESD, 9, 142-146. https://doi.org/10.18178/ijesd.2018.9.6.1089

[2] Abel, C., Dumisani, K., Tapiwanashe, M., and Pardon C. (2014) An Assessment of Irrigation Water Quality and Selected Soil Parameters at Mutema Irrigation Scheme, Zimbabwe. Journal of Water Resource and Protection, 6, 132-140. https://doi.org/10.4236/jwarp.2014.62018

[3] Adris, B., Recep, C., Suat, N. and Pinar, B. (2008) Estimating the Effect of Controlled Drainage on Soil Salinity and Irrigation Efficiency in the Harran Plain Using SaltMod. Turkish Journal of Agriculture and frosty, 32, 101-109.

[4] Ayars, J.E., Christenb, E.W. and Hornbuckleb, J.W. (2006) Controlled Drainage for Improved Water Management in Arid Regions Irrigated Agriculture. Agricultural Water Management, 86, 128-139. https://doi.org/10.1016/j.agwat.2006.07.004

[5] Bahceci, I. and Nacar, A.S. (2008) Subsurface Drainage and Salt Leaching in Irrigated Land in South East Turkey. International Journal of Irrigation and Drainage, 58, 346-356

[6] Hefdhallah, A., Shahien, M., Ogila, W. and Rabie, N. (2013) Drainage Management of Excess Irrigation Water in Arid Area. Proceedings of the Sixth International 
Perspective on Water Resources and Environment, ASCE, Izmir.

[7] Ritzema, H., Kselik, R. and Fernando, C. (1996) Drainage of Irrigation Lands. Irrigation Water Management Training Manual No. 9, FAO.

[8] Ayars, J., Richard, Ir. and Evan, W. (2003) Managing Salinity for Sustainability of Irrigation in Areas With Shallow Saline Ground Water. Proceedings of the 9th International Drainage Workshop, Paper No. 062, Utrecht.

[9] Brouwer, C., Goffeau, A. and Heibloem, M. (1985) Irrigation Water Management: Training Manual No. 1-Introduction to Irrigation, FAO-Food and Agriculture Organization of the United Nations, Rome.

[10] Abdel-Dayem, S. (2000) Drainage Experiences in Arid And Semi-Arid Regions. The World Bank, Washington DC.

[11] Sharma, P. and Tyagi, K. (2004) On-Farm Management of Saline Drainage Water in Arid and Semi-Arid Regions. International Journal of Irrigation and Drainage, 53, 87-103. https://doi.org/10.1002/ird.115

[12] Boumans, J.H. (1987) Drainage in Arid Regions. Proceedings of the 25th International Course on Drainage, Arnhem, Keynote Lectures, 22-43.

[13] FAO (1973) Irrigation, Drainage and Salinity, Paris/UNESCO Hutchinson \& Co, London.

[14] Lambert, K., Willem, F. and David, W. (2004) Modern Land Drainage Planning, Design and Management of Agricultural Drainage Systems. A.A. Balkema.

[15] Craig, R. (2004) Craig's Soil Mechanics. 7th Edition, Taylor \& Francis Group.

[16] John, M., Michael, R., Eugene, H., Michael, K. and Richard, M. (1999) Forest Drainage Engineering. A Design Manual, COFORD National for Forest Research and Development, Agriculture Building, University Collage Dublin, Ireland.

[17] Fox, G.A., Wilson, G.V., Simon, A., Langendoen, E.J., Akay, O. and Fuchs, J.W. (2007) Measuring Stream Bank Erosion Due to Ground Water Seepage: Correlation to Bank Pore Water Pressure, Precipitation and Stream Stage. Journal of Earth Surface Processes and Landforms, 32, 1558-1573. https://doi.org/10.1002/esp.1490

[18] Ouria, A. and Toufigh, M. (2009) Application of Nelder-Mead Simplex Method for Unconfined Seepage Problems. Journal of Applied Mathematical Modeling, 33, 3589-3598. https://doi.org/10.1016/j.apm.2008.12.001

[19] Perzlmaier, S., Muckenthaler, P. and Koelewijn, A.R. (2007) Hydraulic Criteria for Internal Erosion in Cohesionless Soil. Proceedings of Assessment of the Risk of Internal Erosion of Water Retaining Structures: Dams, Dykes and Levees-Intermediate Report of the European Working Group of ICOLD, Contributions to the Symposium in Freising, Germany.

[20] Shaban (2017) Statistical Framework to Assess Water Quality for Irrigation and Drainage Canals. International journal of Irrigation and Drainage, 66, 103-117. https://doi.org/10.1002/ird.2042

[21] Punmia, B.C. (2004) Soil Mechanics and Foundations. 13th Edition, Laxmi Publications $(\mathrm{P}) \mathrm{Ltd}$.

[22] APHA, AWWA and WEF (2012) Standards Methods for the Examination of Water and Wastewater. 22nd Edition.

[23] Phocaides, A. (2007) Technical Hand Book on Pressurized Irrigation Techniques. 2nd Edition, Food and Agriculture Organization of the United Nations (FAO), Rome. http://www.fao.org/docrep/010/a1336e/a1336e00.htm 